\title{
Meta
}

Journal des traducteurs

Translators' Journal

\section{The Influence of Background Information in Translation: Quantity vs. Quality or Both?}

\section{Haeyoung Kim}

Volume 51, numéro 2, juin 2006

Théories et pratiques de la traduction et de l'interprétation en Corée Theories and Practices of Translation and Interpretation in Korea

URI : https://id.erudit.org/iderudit/013260ar

DOI : https://doi.org/10.7202/013260ar

Aller au sommaire du numéro

Éditeur(s)

Les Presses de l'Université de Montréal

ISSN

0026-0452 (imprimé)

1492-1421 (numérique)

Découvrir la revue

Citer cet article

Kim, H. (2006). The Influence of Background Information in Translation: Quantity vs. Quality or Both? Meta, 51(2), 328-342.

https://doi.org/10.7202/013260ar
Résumé de l'article

Cet article a pour but d'explorer la façon de fournir aux étudiants, inscrits aux programmes universitaires de traduction, des outils d'apprentissage qui sont à la fois efficaces et pratiques. En comparant les résultats de deux groupes, cette étude visait à établir si l'accès des traducteurs aux données de fond d'un texte pourrait influencer la qualité de la traduction. Avant d'entamer la traduction en anglais d'un texte coréen, un groupe devait premièrement obtenir les données de fond tandis que l'autre ne pouvait se fier que sur des dictionnaires pour traduire les mêmes documents. Le résultat du travail des deux groupes a été comparé afin d'analyser l'effet de données supplémentaires. La qualité et la quantité d'information obtenue ont aussi été analysées afin de mesurer leur influence sur la qualité de la traduction. 


\title{
The Influence of Background Information in Translation: Quantity vs. Quality or Both?
}

\author{
HAEYOUNG KIM \\ The Catholic University of Korea, Seoul, Korea \\ haeyoungkim@catholic.ac.kr
}

\section{RÉSUMÉ}

Cet article a pour but d'explorer la façon de fournir aux étudiants, inscrits aux programmes universitaires de traduction, des outils d'apprentissage qui sont à la fois efficaces et pratiques. En comparant les résultats de deux groupes, cette étude visait à établir si l'accès des traducteurs aux données de fond d'un texte pourrait influencer la qualité de la traduction. Avant d'entamer la traduction en anglais d'un texte coréen, un groupe devait premièrement obtenir les données de fond tandis que l'autre ne pouvait se fier que sur des dictionnaires pour traduire les mêmes documents. Le résultat du travail des deux groupes a été comparé afin d'analyser l'effet de données supplémentaires. La qualité et la quantité d'information obtenue ont aussi été analysées afin de mesurer leur influence sur la qualité de la traduction.

\begin{abstract}
The purpose of this article is to explore ways to provide effective as well as practical teaching tools that can be utilized in translation courses for undergraduate students. The present study specifically focuses on the effect of having access to background information of the translation. Two groups are compared for this aim. One group was asked to conduct background research on the translation topic prior to engaging in the translation while the other group only had access to dictionaries to carry out the identical task. Students were asked to complete translations from Korean into English. Outputs of the two groups were compared to assess the impact of background information. The quantity and quality of background information were also analyzed to examine their influence on the quality of translation.
\end{abstract}

\section{초록}

본 연구는 학부생들을 대상으로 실시하는 번역 교육의 효율성을 제고할 수 있는 방 법을 살펴보았다. 특히, 번역 수행에 있어서 주제와 관련된 배경 지식의 중요성을 두 집단에 대한 비교 분석을 통해 알아보았다. 한 집단에게는 번역을 수행하기 전 에 주제와 관련된 자료를 수집하고 분석하는 등 사전 준비를 하도록 하였으며 다 른 집단은 사전만을 사용하여 번역을 하도록 하였다. 학생들의 번역을 평가한 후 통계적 분석을 통해 관련 자료 준비의 중요성을 입증하였으며 특히 관련자료의 양 적, 질적인 차이가 번역의 질에 어떤 영향을 미치는지에 대한 분석 결과도 도출하 였다.

\section{MOTS-CLÉS/KEYWORDS}

background information, undergraduate, translation education, quantity, quality

\section{Introduction}

While background information research for the topic of the document to be translated is an indispensable step in the translation process, empirical research on the influence of background information on the quality of translation remains scarce. 
This paper will concentrate on an important, but oftentimes overlooked aspect of translation which has practical pedagogical value in the classroom: the importance of background information and the influence of information quality and quantity on translation performance.

\section{Background}

\subsection{Translation Theory vs. Classroom Reality}

What does it take to be a good translator? According to Gerding-Salas (2000) students should hold (1) sound linguistic training in the two languages, (2) knowledge covering a wide cultural spectrum, (3) high reading comprehension competence and permanent interest in reading, (4) adequate use of translation procedures and strategies, (5) adequate management of documentation sources, (6) improvement capacity and constant interest in learning, (7) initiative, creativity, honesty and perseverance, (8) accuracy, truthfulness, patience, and dedication, (9) capacity for analysis and selfcriticism, (10) ability to maintain constructive interpersonal relationships, (11) capacity to develop teamwork, (12) efficient data processing training at user's level, and (13) acquaintance with translation software for MT (Machine Translation). While the ideal student will possess all of the desirable traits, the real world often displays a quite different picture, especially at the undergraduate level.

Teaching undergraduate students how to translate into a second language is a challenging task. More often than not, students are equipped with neither the proper level of linguistic ability nor the appropriate amount of general background knowledge to carry out translation tasks in an efficient manner. Nonetheless, the trend in English education calls for a more pragmatic approach in training students to achieve a higher level of English proficiency, and as a result courses related to the actual use of English after graduation, such as translation courses, are gaining popularity among not only the school administration but also students (Kim 2004).

While theoretical perspectives on the process of translation provide valuable insight into a complicated procedure, translation theory sometimes seems unhelpful, and even irrelevant, to trainee and practising translators, despite a shift in recent years away from a purely theoretical approach and towards integration of practice (Fraser 1996).

\subsection{Translators and Technology}

When carrying out translation tasks, students must have the necessary resources to deal with the material such as dictionaries, glossaries, and any other resources. Such resources can include websites devoted to translation or terminology, online discussion groups concerning translation, friends or colleagues who work in the profession, and magazines and journals (James 2002). During the past two decades Korea has witnessed a technological revolution that has also had a significant impact on how translators work. A case in point is the personal computer, which has become an irreplaceable tool for translators.

The translation process demands knowledge and skills that range from adequately researching the social and cultural context of the source text, to making the best possible use of dictionaries, general reference books and the Internet. A translator is 
required to obtain a detailed understanding of the content of each sentence. Fieldspecific knowledge plays a critical role in successfully recognizing and understanding the concepts and the linguistic tools that translators use to convey information, to introduce a particular concept, or to argue a certain position. With sufficient background knowledge, one may build upon an accurate analysis of a sentence to establish the main points of the sentence. It is during this process that references such as dictionaries, glossaries, encyclopedias, and websites prove their worth. In particular, the translator must reexamine the source text, consult additional references, or (preferably) both when the apparent meaning (based on textual analysis) of the source text conflicts either with the translator's field-specific knowledge or with information gathered from reliable references (James 2002). This problem is a daunting one for many students. Intermediate-level students frequently indicate in footnotes that they know their translations contain inconsistencies but they cannot identify the source of their misunderstanding (James 2002). Since developing and maintaining familiarity with common patterns of expression in the target language by regularly reading or scanning target language publications either in paper or electronic form are important, students should be provided with instruction specifically dealing with background information pertinent to the translation topic at hand.

\section{Experiment}

\subsection{Research Questions}

The purpose of this study is to examine whether availability of background information of the translation topic has an influence on translation quality. Specifically, the following research questions will be looked into:

1) Is background information associated with translation quality?

2) Which attribute of background information (quality, quantity, or both) affects translation quality?

\subsection{Subjects}

Participants were 32 undergraduate students enrolled in a Korean/English translation course at a university located in Korea. The students were divided in half into two groups - one group was assigned a translation task without any background information and the other was allowed to collect background information to be used in the translation. Table 1 shows the number of participants in each group.

TABLE 1

Number of Participants in Each Group

\begin{tabular}{|l|l|l|}
\hline Group & Experimental Treatment & N \\
\hline Group 1 & No background information & 16 \\
\hline Group 2 & Background information & 16 \\
\hline
\end{tabular}




\subsection{Experimental Procedure}

Because the groups were naturally occurring and not randomized, they needed to be pre-tested for differences in oral proficiency. A pretest was designed to measure the students' initial level of reading proficiency. For the pretest, a reading section of the TOEIC test was administered.

\subsubsection{Pretest: Reading Proficiency Assessment and Survey}

A pretest was administered to measure the students' entry level of reading proficiency. The test which is part of a practice TOEIC reading test consisted of 100 questions testing the ability to understand written English.

\subsubsection{Experimental Treatment}

Students were given a task to be translated from Korean to English (See Appendix A for the original text). Students were divided into two groups. Group 1 was allowed to consult the dictionary while carrying out the translation task. Group 2 was provided with the original text in advance and was allowed to bring in background information on the topic to be translated.

\subsubsection{Translation Quality Assessment}

For the first phase of the study, translations from both groups were graded by three native speakers teaching English courses at the university level. The translations were mixed in random order and judges were not provided with any information regarding the experiment treatment (See Appendix B for Translation Assessment Grid).

\subsubsection{Quality and Quantity Assessment of Background Information}

For the second phase, judges were asked to assess the quality of the background information collected by students in Group 2. The background information was also mixed in random order and judges were unable to associate certain background information with certain translation tasks. The judges ranked the quality of the background information on a scale from 1 (little association with the topic) to 5 (perfect match with the topic). Table 2 presents the criteria that were used to assess the quality of background information. Examples of the background information collected by the students are shown in Appendix C.

The quantity of the background information was represented by the number of words in the articles collected by the students to be used as references for their translation.

TABLE 2

Background Information Quality Assessment Criteria

\begin{tabular}{|l|l|}
\hline Score & Criteria \\
\hline 0 & No relationship with the topic (e.g., Rock band named "Fast Food") \\
\hline 1 & $\begin{array}{l}\text { Little relationship with the topic (e.g., Anti-American sentiment reflected on the } \\
\text { fast food industry) }\end{array}$ \\
\hline 2 & $\begin{array}{l}\text { Deals with the area of the topic in a broad sense but does not touch upon the } \\
\text { topic (e.g., Foreign food chains) }\end{array}$ \\
\hline
\end{tabular}




\begin{tabular}{|l|l|}
\hline 3 & Corresponds with the topic in a broad sense (e.g., Fast food chains) \\
\hline 4 & $\begin{array}{l}\text { Deals specifically with the topic (ex. McDonald's in the Gulf to launch new } \\
\text { 'Quality' awareness campaign) }\end{array}$ \\
\hline 5 & $\begin{array}{l}\text { Almost exact match (ex. McDonald's Australia will make history by opening its } \\
\text { doors to customers) }\end{array}$ \\
\hline
\end{tabular}

\subsection{Data Analysis}

Table 3 summarizes the experimental procedure of the study.

TABLE 3

Experiment and Analysis Procedure of the Study

(Phase 1) Comparison between Groups

Group 1 vs. Group 2 (No background information vs. Background information)

(Phase 2) Comparison within Group 2

Quality vs. Quality of background information

For an analysis of the pretest and the translation quality (Phase 1), analysis of covariance (ANCOVA) was used. Pretest measures of students' oral proficiency were used as a covariate, and the translation grade as a dependent variable. The two groups were the fixed factors.

For an analysis of the background information and its effect on translation quality (Phase 2), multiple regression was used. Background information quantity, quality, and TOEIC reading test score were independent variables and translation grade was the dependent variable.

\section{Result and Discussion}

\subsection{Effects of Availability of Background Knowledge: Phase 1}

Descriptive statistics in Table 4 show some differences in pretest scores and in translation scores between the two groups.

TABLE 4

\section{Descriptive Statistics}

\begin{tabular}{|l|l|l|l|l|}
\hline Instructional Contexts & $\begin{array}{l}\text { TOEIC } \\
\text { Mean }\end{array}$ & $\begin{array}{l}\text { TOEIC } \\
\text { SD }\end{array}$ & $\begin{array}{l}\text { Translation } \\
\text { Mean }\end{array}$ & $\begin{array}{l}\text { Translation } \\
\text { SD }\end{array}$ \\
\hline No Background & 65.6250 & 10.50635 & 27.3750 & 5.13647 \\
\hline Background & 64.2500 & 10.84128 & 31.5000 & 6.34560 \\
\hline
\end{tabular}

The test of between-subject effects is summarized in Table 5. The effect of availability of background information was found to be statistically significant $[\mathrm{F}(1$, $29)=3.37, \mathrm{p}=.048$ ]. The significant values in Table 5 show that the covariate (TOEIC reading scores) does not predict the dependent variable (translation score) in a statistically significant manner since the significance value exceeds .05. Therefore transla- 
tion scores do not appear to be influenced by TOEIC reading scores. Background information, on the other hand, is a statistically significant factor in predicting students' translation scores $(\mathrm{p}=.04)$.

TABLE 5

Tests of Between-Subjects Effects

\begin{tabular}{|l|l|l|l|l|l|}
\hline Source & Sum of Squares & df & Mean Square & F & Sig. \\
\hline Corrected Model & 214.384 & 2 & 107.192 & 3.373 & .048 \\
\hline Intercept & 304.145 & 1 & 304.145 & 9.572 & .004 \\
\hline Pretest (TOEIC) & 78.259 & 1 & 78.259 & 2.463 & .127 \\
\hline Background Information & 149.540 & 1 & 149.540 & 4.706 & .038 \\
\hline Error & 921.491 & 29 & 31.776 & & \\
\hline Total & 28866.000 & 32 & & & \\
\hline Corrected Total & 1135.875 & 31 & & & \\
\hline
\end{tabular}

a Computed using alpha $=.05$

b $\quad$ R Squared $=.189$ (Adjusted R Squared $=.133$ )

Levene's Test in Table 6 is not significant, indicating that the group variances are equal and hence the assumption of homogeneity of variance has not been violated.

TABLE 6

Levene's Test of Equality of Error Variances

Dependent Variable: Translation Score

\begin{tabular}{|c|c|c|c|}
\hline F & df1 & df2 & Sig. \\
\hline 3.579 & 1 & 30 & .068 \\
\hline
\end{tabular}

Tests the null hypothesis that the error variance of the dependent variable is equal across groups.

a Design: Intercept+TOEIC reading +Background Information

\subsection{Analysis of Background Information: Phase 2}

In order to examine the contribution of background information quantity and quality on translation scores, multiple regression was performed with background information quantity and background information quality as independent variables. Translation scores were the dependent variable. Table 7 shows the mean and standard deviation of the translation score, number of words in the articles gathered for background information and article quality of Group 2.

TABLE 7

\section{Descriptive Statistics}

\begin{tabular}{|l|l|l|}
\hline & Mean & Std. Deviation \\
\hline Translation Score & 31.5000 & 6.34560 \\
\hline Info Quantity (Word Count) & 1613.3750 & 740.45012 \\
\hline Info Quality & 2.7500 & 1.77012 \\
\hline
\end{tabular}

Note. $\mathrm{N}=16$ 
Table 8 gives details of the correlation between each pair of variables. The correlation among the variables shows that background information quality is strongly related to translation score $(\mathrm{r}=.867)$ but background information quantity is not $(\mathrm{r}=.109)$.

TABle 8

\section{Correlations}

\begin{tabular}{|l|c|c|c|}
\hline & $(1)$ & $(2)$ & $(3)$ \\
\hline (1) Translation Score & 1.000 & .109 & $.867^{\star}$ \\
\hline (2) Background Information Quantity & .109 & 1.000 & $.505^{\star}$ \\
\hline (3) Background Information Quality & $.867^{\star}$ & $.505^{\star}$ & 1.000 \\
\hline
\end{tabular}

Note. ${ }^{*}$ indicates statistical significance.

The adjusted R-square (.880) in Table 9 tells us that the model accounts for $88 \%$ of variance in the translation score. In other words this model can predict translation quality almost $88 \%$ correctly.

TABLE 9

Model Summary

\begin{tabular}{|c|c|c|c|c|}
\hline Model & $\mathrm{R}$ & $\mathrm{R}^{2}$ & Adjusted $\mathrm{R}^{2}$ & Std. Error of the Estimate \\
\hline 1 & .947 & .896 & .880 & 2.19907 \\
\hline
\end{tabular}

a Predictors: (Constant), quality of articles, word count

Standardized Beta Coefficients in Table 10 give a measure of the contribution of each variable to the model. A large value indicates that a unit change in this predictor variable has a large effect on the criterion variable. The $t$ and Sig. $(p)$ values give a rough indication of the impact of each predictor variable - a big absolute t value and small $\mathrm{p}$ value suggests that a predictor variable is having a large impact on the criterion variable. Thus the Beta in Table 10 shows that background information quality is a significant predictor of translation score (Beta $=1.089, \mathrm{t}=10.508, \mathrm{p}<.05$ ), while quantity is not.

TABLE 10

Coefficients

\begin{tabular}{|l|c|c|c|c|c|}
\hline & $\begin{array}{c}\text { Unstandardized } \\
\text { Coefficients (B) }\end{array}$ & $\begin{array}{c}\text { Std. } \\
\text { Error }\end{array}$ & $\begin{array}{c}\text { Standardized } \\
\text { Coefficients (Beta) }\end{array}$ & $\mathrm{t}$ & Sig. \\
\hline (Constant) & 26.862 & 1.386 & & 19.377 & .000 \\
\hline Quantity & $-3.781 \mathrm{E}-03$ & .001 & -.441 & -4.256 & .001 \\
\hline Quality & 3.905 & .372 & 1.089 & 10.508 & .000 \\
\hline
\end{tabular}

a Dependent Variable: Translation score

\section{Conclusion}

The study examined the effect of background information on translation quality. The study further went on to inquire whether the quality and quantity of background 
information gathered had any influence on the quality of translation. Results indicate that having access to background information does have an effect on translation quality. Interestingly, however, students' TOEIC reading scores which reflect their general English reading ability do not appear to affect translation quality. In other words, it is the background information rather than the a priori English reading proficiency level that has a more significant influence on the outcome of the translation. The study also found that while background information quality had a significant influence on the translation quality, background information quantity had little effect.

Findings of the study emphasize not only the importance of background information per se, but also its quality in order to ensure translation quality. As is shown in the examples of background information, students these days rely on the Internet in search of resources. However, students in the undergraduate level lack sufficient degree of skills to differentiate authentic, high-quality texts from sources that appear authentic but are actually of little use. As shown in the examples of background information in Appendix C, inappropriate content not only has little utility but also can actually interfere with the translation process and produce translation of poor quality.

Instructors who train students to translate into L2 must take extra precautionary measures to warn students of the pitfall of granting blind trust to everything posted online. One way to do so is to guide students to consult search engines of the target language. A surprising number of students relied more on Korean search engines than English sites in this study.

Cross checking is another method of making sure that the information obtained in one source is confirmed by another online source. In other words, students should always be reminded to be on guard for false or inappropriate information by confirming the veracity of their findings by consulting other sources.

When consulting online sources, one of the most difficult problems facing students is the huge amount of results or 'hits.' Instructors should emphasize the importance of figuring out the main idea of the original text and identifying target words before consulting online resources. For example, using only 'McDonald's' as the key word in the search covers too wide a range. Instead, words such as 'open,' 'quality,' 'kitchen,' 'tour,' in addition to McDonald's narrowed the topic down to a manageable level. Since the amount of information gathered did not help much to improve students' translation output, efficiency in searching for appropriate resources should be emphasized when instructing students.

Introducing students to a wide range of sources is a quick and easy way to steer students away from making mistakes that could easily have been prevented. What is regarded as standard routine for professional translators may and often does come as a novelty to students.

\section{REFERENCES}

Fraser, J. (1996): “Mapping the Process of Translation,” Meta 41-1, p. 84-96.

GABR, M. (2002): "A Skeleton in the Closet: Teaching Translation in Egyptian National Universities," Translation Journal 6-1, <http://accurapid.com/journal/19edu.htm $>$.

Gerding-Salas, C. (2000): “Translation: Problems and Solution," Translation Journal 4-3, <http: //accurapid.com/journal/13edu.htm>.

James, D. (2002): “Teaching Japanese-to-English Translation," Japan Association of Translators, $<\mathrm{http}: / /$ www.jat.org/jtt/teachtrans.html $>$. 
KIm, H. (2004): “Teaching Translation into the Second Language to Undergraduate Students: Importance of Background Knowledge and Parallel Texts," Forum 2-1, p. 29-45.

\section{List of Sources of Text Samples}

Dong-A Ilbo (May 17, 2004): 맥도날드 “매장 속살까지 다 보여드립니다” 주방공개 행사 (Original Korean Text).

McDonald's set to make history with public tours of restaurants. (June 27, 2003): <http://www. mcdonalds.com.au/home/structure.asp? ID $=>$.

McDonald's in the Gulf to launch new 'Quality' awareness campaign (Sunday, June 22, 2003): $<\mathrm{http} / /$ www.ameinfo.com/cgi-bin/cms/page.cgi? page=print;link=25347 $>$.

Fast Food Fascism (2003): <http://www.commondreams.org/views03/0123-09.htm>.

Foreign food chains spice up marketing (2002): <http://www.foodikorea.com/english/news/ news02_view.asp?ns_no $=2051$ \&page $=1 \&$ menu $=$ sja $\&$ search $=$ foreign $\% 20$ food $\% 20$ chains $\% 2$ 0spice\%20up\%20marketing $>$.

Fast Food in a Rapid Decline - Anti-American mood, health concern hurt sales $<$ http://foodikorea.co.kr/english/news/news02_view.asp?ns_no $=5711$ \&page $=11 \& s j \_p a r t=02>$.

A brief history of the band: <http://www.summerbash.de/bash/2004/fastfood.htm>.

\section{Appendix A}

\section{Original Korean Text}

2004.5.16 (일) 18:30 동아일보

맥도날드 “매장 속살까지 다 보여드립니다" 주방공개 행사

[동아일보]

한국맥도날드가 ‘반(反)건강식품’ 이미지에서 벗어나기 위해 다양한 마케팅에 나 섰다.

한국맥도날드는 6월 6일 전국 340 개 매장의 주방을 공개해 소비자에게 조리 과정 을 보여주는 '오픈 데이(Open Day)' 행사를 연다고 16일 밝혔다.

전 세계 120 여 나라에 진출해 있는 맥도날드가 주방을 공개한 것은 호주에 이어 한국이 두 번째.

한국맥도날드 신언식 사장은 “맥도날드는 무조건 건강에 해로운 것처럼 지나치게 공격 당해 왔다”며 “우리 제품이 얼마나 깨끗하고 엄격한 과정을 거쳐 만들어지 는지 소비자에게 공개해 정당한 평가를 받겠다”고 말했다.

9세 이상 초등학생부터 참가가 가능하며 31일까지 한국맥도날드 홈페이지 (www. mcdonalds.co.kr)에서 원하는 매장과 시간을 선택해 참가 신청서를 작성하면 된 다.

한국맥도날드는 지난달부터 쇠고기, 빵, 감자 등 재료의 영양 정보와 메뉴별 열량 을 홈페이지에 공개하는 ‘퀄리티 캠페인’을 벌이고 있다.

\section{Appendix B}

\section{Translation Assessment Grid}

\begin{tabular}{|l|l|}
\hline \multicolumn{2}{|l|}{ Substance } \\
\hline ( ) & Conveys message clearly (5) \\
( ) & Conveys message adequately (3) \\
( ) & Conveys message inadequately (1) \\
\hline \multicolumn{2}{|l|}{ Mechanical Errors } \\
\hline ( ) & No mechanical errors (5) \\
( ) & May have a few minor mechanical errors that do not interfere with comprehension (4) \\
( ) & Some mechanical errors: Problems with spelling, punctuation, etc. do not interfere \\
& with comprehension (3) \\
( ) & Many mechanical errors that may interfere with comprehension (2) \\
( ) & Gross mechanical errors that may be very difficult to decipher (1) \\
\hline
\end{tabular}




\begin{tabular}{|l|l|}
\hline \multicolumn{2}{|l|}{ Sentence Structure } \\
\hline$($ ) & Good sentence structure (5) \\
$($ ) & Good sentence structure (e.g., all sentences are complete) (4) \\
$($ ) & Adequate sentence structure (e.g., most sentences are complete) (3) \\
( ) & Weak sentence structure; incomplete sentences or poorly structured sentences (e.g., \\
& comma splices, fused sentences) (2) \\
( ) & Overall lack of proper sentence structure (1) \\
\hline Style & \\
\hline ( ) & Smooth and logical style (5) \\
( ) & Adequate style: Sentences may be somewhat choppy. Overall message may not be \\
& completely smooth or logical (3) \\
( ) & Inadequate style: Choppy sentences. Overall message is not delivered. (1) \\
\hline
\end{tabular}

Rank from 1 to $5 .(5=$ competent, $1=$ needs improvement $)$

\begin{tabular}{|l|l|}
\hline ( ) & $\begin{array}{l}\text { Use of Appropriate Layouts / Formats: Knowing and using the right layout or format } \\
\text { of the text. }\end{array}$ \\
\hline ( ) & $\begin{array}{l}\text { Appropriate Register: Correct formality and politeness for the situation. Using the } \\
\text { same type of words as a professional in the field; e.g., a computer professional should } \\
\text { talk and write about 'peripherals', not 'things you connect to your computer." }\end{array}$ \\
\hline ( ) & $\begin{array}{l}\text { Accuracy of Vocabulary and Grammatical Structures: Using correct grammar and } \\
\text { vocabulary. }\end{array}$ \\
\hline ( ) & $\begin{array}{l}\text { Range of Vocabulary and Grammatical Structures: Vocabulary and grammar that } \\
\text { express ideas well }\end{array}$ \\
\hline ( ) & $\begin{array}{l}\text { Compliance with Academic Writing Conventions: Following the commonly accepted } \\
\text { way professional writers write this kind of text. }\end{array}$ \\
\hline
\end{tabular}

Appendix C

\section{Examples of Background Information}

\section{Score 5}

McDonald's set to make history with public tours of restaurants.

Friday, June 27, 2003

McDonald's Australia is set to create history on July 5 when it opens the doors of around 600 restaurants and invites the public into its kitchens to take a behind-the-scenes look at Australia's leading quick service restaurant.

People can register for an Open Doors tour and see for themselves just what goes on in a McDonald's kitchen, what is stored in the fridge and freezer and just how the nation's most popular burger - the Cheeseburger - is made.

People wanting to join Open Doors have until 5pm (AEST) on July 2 to register for the restaurant and kitchen tours which will be held between 9am and 5pm on Open Doors day, Saturday, July 5.

Guy Russo, Managing Director of McDonald's Australia said Open Doors day was designed specifically for customers and others interested in seeing what goes on behind the counter of Australia's most popular quick service restaurant.

"I started working at McDonald's when I was just 15 - it's a company that I'm very proud of and I'd love our customers to learn a little bit more about what we do and how we do it," Mr. Russo said.

"The restaurant tours, kitchen visits and discussion forums will give visitors the opportunity to ask questions about anything - from the preparation of our burgers, to the source of our products, or the training we provide our staff.

"Research has shown that customers are amazed to hear the truth about our food and McDonald's commitment to quality. There are a range of urban myths surrounding our food 
and for many people the simple facts are quite surprising. No one is more interested than me in setting the record straight and making sure everyone knows the facts about our food." McDonald's Open Doors day is part of a rigorous new approach by the company which has seen it launch an intense focus on menu choice, food quality and food facts in 2003. In February McDonald's introduced a new Happy Meal with a toasted cheese and tomato sandwich, sultanas and orange juice. It is also trialing a new breakfast range including cereal, fruit tubs, yoghurt and juices, which will be available nationally by the end of this year. In May McDonald's updated its nutrition brochure and website www.mcdonalds.com.au giving customers an in-depth analysis of the energy, protein, fat, carbohydrate, sugars and sodium content of regular menu items - the website now includes a nutrition counter.

By the end of the year McDonald's will also launch a new range of menu items which will include lighter and healthier food offerings.

People can book for an Open Doors tour at www.mcdonalds.com.au or by calling the Open Doors Customer Hotline on 1300309622 (local call costs apply from landlines and calls are extra from mobiles, depending on your provider). Bookings can be made from June 25 until July 2.

For health and safety reasons there are a set of terms and conditions for tour participants. People will be made aware of these when booking their tours.

- McDonald's Open Doors will not be running at express restaurants or food court restaurants.

- For health and safety reasons, only people over the age of 14 years can participate in restaurant tours. Those less than 18 years will need to be accompanied by a parent or other responsible adult.

- All tour participants will be given a hairnet and coat to wear during the tour.

- For more health and safety information about the day visit www.mcdonalds.com.au

- Bookings can be made between 9am and 5pm (AEST), June 25 to July 2.

\section{Score 4}

\section{McDonald's in the Gulf to launch new 'Quality' awareness campaign}

Building on McDonald's transparency and openness policy with its customers, McDonald's independent owners throughout the GCC announced the launch of a showcase campaign reinforcing that commitment.

\section{United Arab Emirates: Sunday, June 22, 2003}

"The new Quality campaign focuses on creating awareness about McDonald's exceptional quality and quality control protocols. McDonald's has implemented rigorous food safety and quality standards for almost 50 years. In the GCC, and since the opening of our first stores, we have aimed at exceeding these standards in the interest of our customers. For example, with regards to beef, McDonald's only uses pure flank and forequarter beef that undergoes around 50 separate quality tests before it is served to customers. No additives or preservatives are added, and the only seasoning used is a little salt and pepper. In the GCC, we have additional tests and third party quality controls to ensure that our beef is Halal, and that it complies and exceeds local health authority requirements." Said Dr. Habib M'Nasria, Quality Assurance Manager for McDonald's in the Middle East. Rafic Fakih, Managing Director of McDonald's in the UAE added: "McDonald's serves the same food that people normally eat at home: Meat, chicken, fish, potatoes, bread, and salads. The only difference is that our food undergoes some of the most extensive food quality controls in the world - from farm to counter. The new campaign is designed to communicate this with our customers and to reinforce their trust in our brand."

The campaign started with invitations to select schools and journalists to visit McDonald's kitchens and examine first hand the quality procedures in place at the restaurants. A television commercial supported by advertisements in the newspapers and posters inside the restaurants will be relied on to broaden the awareness among all customers. "We are very excited by this challenge," said Alsharif Abdallah, Marketing and Communications Director. "We have always practiced a policy of crystal clear transparency with our customers. We are 
proud of the quality of the food that we serve, and want all our customers to know it. The campaign that we have in place is more than a commercial about the quality of our beef, chicken, or fries. It is a clear communication of McDonald's values of caring for its customers and providing them with the best quality, service, cleanliness and value - the qualities that made it the world's favorite family restaurant."

Mr. Abdullah concluded: "We consider our suppliers as partners in sustaining quality and supplying us with fresh products, as we expose them to a long list of conditions and details that they have to follow with their employees, premises and products in order to best service our clients."

McDonald's is the world's leading food service retailer with more than 30,000 local McDonald's restaurants serving 46 million customers each day in more than 100 countries.

\section{Score 3}

\section{Fast Food Fascism}

McDonald's is under attack these days, but for all the wrong reasons. Yes, the fast food industry sells unhealthy food. Yes, it induces people to overeat for profit. Yes, ranchers cut down rain forests to supply it with cattle. Yes, that reduces the world's oxygen supply. But the real crime of McDonald's - supposedly the shining symbol of American capitalism - is that it is truly and deeply anti-American.

The fast food industry stands against the personal values that made this country great: rugged individualism, originality, creativity, a sense of adventure, non-conformity, and above all, allaround fearlessness.

In an effort to standardize products and maximize profits, the fast food industry has infected America with an insidious creeping fascism that was never political in itself, but which has had deeply political consequences.

Sit in a McDonald's for a half hour with a critical eye. The lights are glaring; there's no relaxation or goodwill to go along with the food. The chairs and tables are bolted to the ground. You can't draw up a chair to another table, for example, or join a larger group. Even if you're uncomfortably close to the table, there is nothing you can do except accept the discomfort. It's like a prison cafeteria; shut up and eat.

The foliage, furniture, plates, utensils and cups are plastic. You are completely disconnected from the natural world. All the decoration is advertisement. It's no wonder so many people wear corporate logos on their clothes and think it's right to put advertisements in schools; they're completely desensitized; life doesn't exist outside of commercials.

Fast food restaurants create a false sense of abundance. They offer access to a ready supply of condiments, sugar packets, straws, napkins and coffee cream - things that cost the restaurant almost nothing and have no real value.

They also offer a false sense of control. You appear to have many choices - a Big Mac, a cheeseburger, a quarter pounder, a double quarter pounder or a "Big 'N' Tasty" - but they're all pre-packaged, frozen, pre-cooked hamburger. If you want to be radical, have fried chicken, fried fish pieces, even flatbread sandwiches. But you have no control over portion size, or the way your meal is cooked.

One of the ways we learn who we are is by the choices we make. Being given free reign to make meaningless choices translates directly into the political arena, where we are asked to make empty choices between multi-millionaires and the almost identical political parties which own them.

The overworked and over-managed young food zombies in fast food restaurants are being trained to accept a lifetime of deadening and unfulfilling jobs. They learn early that making suggestions and demands will get you fired. Fear plays a large part in this kind of work; I once took out a notebook in McDonald's and the young manager looked panic-stricken. He was probably afraid of his own managers.

In order to navigate the world intelligently, we need our language to be clear and wellgrounded. McDonald's corrupts language. What on earth is a "McSalad"? A "Happy Meal?" A "Mighty Kids Meal?" 
Many books have been written about the frighteningly poor quality of fast food. Eric Schlosser's "Fast Food Nation: The Dark Side of the All-American Meal" is a revelation. A new book by Greg Critser, "Fat Land: How Americans Became the Fattest People in the World," reveals how the fast food industry discovered that Americans are so ashamed of appearing gluttonous that they won't order two orders of fries. In response, the industry created "supersized" portions and along with it, a nation of supersized people.

Once you have accepted standardization in fast food restaurants, you may be unquestioning about it in other places. In my supermarket, all the pork is now pre-packaged by a company called Smithfield. The packaging offers a list of ingredients: pork broth, potassium lactate, salt, sodium phosphates, and natural flavorings; shouldn't the only ingredient in a pork roast be pork?

The fast food industry is now under attack from many sides. McDonald's stock has lost half its market value in the last two years; it has closed more than 100 restaurants and fired its CEO. Its arch enemy, Burger King, was on the market for two years without finding a taker; it recently sold at a discounted price that dropped from $\$ 2.3$ billion to $\$ 1.5$ billion in just six months.

Obese people are suing fast food restaurants here, while abroad, they are being attacked for corporate imperialism. McDonald's, with 23,000 restaurants in about 121 countries, has been attacked in China, Denmark, France, Bangalore, Colombia, Russia, Argentina, Belgium, South Africa and Great Britain.

My own private rebellion against fast food restaurants dates back 30 years, as I watched juicy fresh hamburgers and fried chicken disappear all across the country, along with the small, quirky family-owned restaurants that served them.

Why, I wondered, as Americans grew wealthier, did they also grow so timid? Why did they reject the adventure of discovery, of making choices, of exploring the world? Why were they willing to sacrifice flavor, freshness, variety and a strong connection to the natural world for safe, predictable, boring and homogenized food? I can't blame the fast food industry for being so eager to oblige them.

I may be leaving myself open to a charge of elitism here, but no, I don't want to become a vegetarian, and no, I don't think that wanting restaurants to serve the kind of fresh, tasty, wholesome and inexpensive food that I remember from my childhood makes me a snob. By unquestionably accepting the corruption of their food, Americans have come to accept the corruption of just about everything else - low pay, out-of-reach health care, corporate corruption, irrational wars, tax breaks for the rich, and McPresidents of the United States. Today there are thousands of fast food restaurants and millions of people who actually believe this is the way food should be. Is it such a great step to thinking that Americans will also accept a degraded form of something as complex, difficult and demanding as real democracy?

\section{Score 2}

\section{Foreign food chains spice up marketing}

A number of foreign food chains in Korea, which are doing great business despite the ongoing economic downturn, are working to maintain their success by launching new and creative marketing strategies.

The latest campaigns include holding Halloween events, publishing "infotainment" magazines, upgrading cyber marketing and offering free cooking classes.

In time for the upcoming Halloween holiday (Oct. 31), Hardrock Café in Cheongdam-dong will throw a special party tonight involving costumes and contests.

During the evening, all restaurant staff will be dressed as either nurses or nine-tailed foxes with "best dresser" and "imitating movie characters" contests. The winner will be awarded a bottle of the Bacardi premium rum.

Family restaurant Marché is introducing a new menu Oct. 26-31 using pumpkin, the traditional Halloween food. The dishes include pumpkin pie and sweet pumpkin salad and the interior will match the food - the place will be filled with pumpkin lamps and pumpkin dolls. Visitors can also get their faces painted like ghosts after dining. 
Bennigan's is holding a "Horror Halloween Party" Oct. 31 in which staff will be dressed like pumpkin ghosts, Count Draculas, mummies and witches.

Yet another fresh marketing example is T.G.I. Friday's new magazine publication "T.G.I. Friday's." Filled with information and entertainment articles, the bi-monthly, English-language magazine targets expatriates in Korea and foreign tourists. The first issue, which came out this month, was packed with interview stories, travel guides, introductions of new menus and scoops on special events like the "2001 Asia Bartender championship."

"This is just one of the services we are offering our customers who have helped us grow so fast," T.G.I. Friday's president Seal Lee said.

The free magazines are available at the Incheon International Airport, Itaewon Travel Information Center, City Airport Terminal and other travel-related venues.

Cyber marketing is yet another hot strategy with most big chains operating their own homepages. But more competitive companies have updated their info-sites to include games, chatting services and cyber money systems.

Burger King launched a homepage (www.burgerking.co.kr) last month offering chatting, game, and online shopping services to its members. The fast food chain is also offering cyber money and "BK points," which give regular online users chances to win free gifts.

McDonald's Korea (www.mcdonalds.co.kr) and T.G.I. Friday's also began giving free monthly cooking lessons to its customers in April. Taking place at the employee training center at T.G.I. Friday's Academy in Sando-dong Seoul, the restaurant taught Italian cooking in April, Mexican in May and Texan in June.

\section{Score 1}

Fast Food in a Rapid Decline - Anti-American mood, health concern hurt sales Agent 007 met a quick death in Korea, overtaken and buried by events. Outlets of Western fast food chains are trying to avoid a similar fate.

Over the nine days since Die Another Day, the James Bond thriller, opened in Korea, only 460,000 people have seen the film, the worst drawing of any 007 series here, an industry source said. The great thud is being attributed to the negative way Koreans say their country is portrayed in the movie and dissatisfaction with Korea's role in its alliance with the United States.

The clamor has not gone unnoticed by U.S.-based companies that worry growing antiAmerican Sentiments might lead to boycotts of their products. Fast food restaurants with their high visibility, are gauging the trend, although there is no hard evidence that they have been caught in the emotional whirlwind. But industry sales were up only 1.8 percent last year, a sharp decline compared with 34.1 percent growth in 2000 and 13.8 percent in 2001, according to industry officials.

McDonald's Korea has taken the lead in product diversification and marketing to boost sales by offering more of a local mélange, which hopefully will divert any anti-Americanism aimed at it. "Our whole crew at McDonald's Korea, is Korean," says a recent McDonald's television commercial.

"All the workers at the Korean subsidiary are Korean, but the brand has always been boycotted whenever relations between Korea and the United States become tense," an official at McDonald's Korea said. The official said Kimchi and Bulgogi burgers were created to appeal to Korean tastes and nationalistic feelings.

\section{Score 0}

\section{A brief history of the band}

Fast Food Orchestra has been running since 98.' As band in today's contents they went through punk and ska-punk but it's been more than 4 years since they came up to the traditional ska more than anything else.

They have released 2 long-play albums, first Fugison party which shows Fastfood in its skapunk days and Last food, album which they produced themselves on their label Jahquita. This 
as yet last album with clearer but stronger sound in overall brings ska based riffs with roots based in Jamaica.

2002-2003, these were the years when the band came through lots of festivals all around and found its fans. Fastfood has been producing several new songs which today makes a long play album, yet not recorded. Yes, the band works on last few things and then let's go to record it. Third album is on its way and hopefully it will be out ending this year 2004 .

It's been more than a year when the band came across a raggamuffin mc dr. Kary which as a special guest of them is bringing more ragga roots into their todays traditional ska sound. Since the beginning - Fastfood has had a chance to play with the following selected bands on one podium: Yellow Umbrella (DE), Skatalites (JAM), Slackers (US), Hotknives (GB), Selecter (GB), Panteon Rococo (MEX) and many many others. 